Kumawula, Vol. 3, No.1, April 2020, Hal 73 - 86 DOI:http://10.24198/kumawula.v3i1.25244

ISSN 2620-844X (online)

Tersedia online di http://jurnal.unpad.ac.id/kumawula/issue/view

\title{
SOSIALISASI DAN EDUKASI KANGPISMAN (KURANGI, PISAHKAN DAN MANFAATKAN SAMPAH)
}

\author{
Bintarsih Sekarninngrum $^{1} *$, Yogi Suprayogi $S^{2}$, Desi Yunita ${ }^{3}$ \\ ${ }^{1,3}$ Departemen Sosiologi, Fakultas Ilmu Sosial Dan Ilmu Politik, Universitas Padjadjaran \\ ${ }^{2}$ Departemen Administrasi Publik, Fakultas Ilmu Sosial Dan Ilmu Politik, Universitas Padjadjaran \\ *bintarsihcat@yahoo.com
}

\begin{abstract}
ABSTRAK
Penanganan permasalahan sampah di Kota Bandung harus dimulai dari sumbernya yaitu rumah tangga dengan melibatkan partisipasi aktif masyarakat. Tujuan kegiatan yaitu memberikan pemahaman dan kemampuan masyarakat dalam melakukan pengelolaan sampah, sehingga memiliki kesadaran sosial untuk merubah perilaku dalam mengolah sampah melalui "Gerakan Kangpisman". Sasaran kegiatan adalah masyarakat aktif, sehingga diharapkan ke depannya menjadi motor penggerak dalam melaksanakan Gerakan Kangpisman. Metode kegiatan dilakukan melalui penyuluhan dan praktek tentang pengolahan sampah. Meteri penyuluhan meliputi permasalahan sampah di Kota Bandung, solusi penanganan sampah, program Kangpisman, alur pengelolaan sampah, pembagian kerja dalam pengelolaan sampah, jadwal kerja dalam pengelolaan sampah, pihak yang terlibat dalam pengelolaan sampah, dan manfaat yang diperoleh dalam pengelolaan sampah. Selanjutnya materi edukasi meliputi praktek pengolahan sampah organik dan anorganik, pembuatan Mikro Organisme Lokal (MOL), pengenalan urban farming, pengenalan hasil kerajinan daur ulang sampah, door to door education dan door to door collection. Hasil dari kegiatan sosialisasi dan edukasi menunjukkan bahwa program Kangpisman telah tersosialisasi di seluruh wilayah dan sekaligus meningkatkan kapasitas kelembagaan Tim Penggerak PKK sebagai motor penggerak dari program Kangpisman.
\end{abstract}

Kata Kunci: Kawasan Bebas Sampah, Pengelolaan Sampah, Kangpisman, Door to Door Education, Door to Door Collection

\section{KANGPISMAN'S SOCIALIZATION AND EDUCATION (REDUCE, REUSE AND RECYCLE)}

\begin{abstract}
The problem of waste in the city of Bandung, which must start from the source, namely the household, by involving the active participation of the community. The purpose of this activity is to provide understanding and ability of the community in processing waste, so that they have a social awareness to change behavior in processing waste through the "Kangpisman" movement. The target activity is the active community, so it is expected that in the future it will become a driving force in implementing the Kangpisman Movement. The method used in this activity is counseling and waste management practices. Counseling material covers the problem of waste in the city of Bandung, waste handling solutions, Kangpisman program, waste management flow, division of work in waste management, work schedule in waste management, parties involved in waste management, and benefits obtained in waste management. Furthermore, educational material covers the practice of processing organic and inorganic waste, making local microorganisms, the introduction of urban
\end{abstract}


farming, the introduction of the results of waste recycling crafts, door to door education and door to door collection. The results of the socialization and education activities showed that the Kangpisman program had been socialized throughout the region and at the same time increasing the institutional capacity of the Family Welfare Empowerment mobilizing team as the driving force of the Kangpisman program.

Keywords: Waste Free Area; Waste management; Kangpisman; Door to Door Education; Door to Door Collection

\section{PENDAHULUAN}

Sampah merupakan masalah faktual yang dihadapi wilayah perkotaan di Indonesia. Mengatasi masalah sampah tidak hanya menjadi tanggung jawab pemerintah, tetapi harus ada kesadaran dan partisipasi dari masyarakat. Kota Bandung, dengan jumlah penduduk 2.497.938 jiwa dan tingkat kepadatan penduduk sebesar 14,93 ribu jiwa/km2 (Apriadi, 2018) telah menjelma menjadi kota Metropolitan. Semakin meningkatnya populasi penduduk, memiliki konsekuensi meningkatnya jumlah sampah yang diproduksi oleh kota Bandung. Produksi sampah kota Bandung per harinya mencapai 1600 ton, dari jumlah tersebut sepertiga nya tidak tertangani oleh pemerintah (Permana, 2018).

Mengingat masih adanya sampah yang tidak tertangani, pemerintah Kota Bandung mencari solusi penanganan sampah melalui pelibatan masyarakat dalam pengelolaan sampah. Upaya tersebut selain untuk meningkatkan kepedulian masyarakat dalam mengelola sampah, juga diharapkan dapat menekan biaya yang harus dikeluarkan oleh pemerintah dalam mengatasi permasalahan sampah. Salah satu program pemerintah untuk mengatasi permasalahan sampah yaitu mewujudkan Kawasan Bebas Sampah. Kawasan Bebas Sampah adalah suatu kawasan dimana sistem pengelolaan sampahnya dijalankan secara mandiri oleh masyarakat. Sebuah kawasan disebut sebagai Kawasan Bebas Sampah, jika tidak ada sampah bertebaran di seluruh kawasan, baik di jalan, selokan/sungai, Tempat Pembuangan Sampah (TPS) area pasar atau daerah komersil dan tempat lainnya. Program Kawasan Bebas Sampah dimaksudkan untuk mengubah gaya hidup masyarakat dalam mengolah sampah, dan diharapkan tidak ada lagi sampah yang dibuang ke Tempat Pembuangan Akhir (TPA) sampah.

Pemerintah menyadari bahwa permasalahan sampah di Kota Bandung terjadi karena masyarakat tidak terlibat dalam proses pengelolaan sampah. Pemerintah mendorong masyarakat untuk terlibat dan peduli atas sampah yang dihasilkan oleh rumah tangga. Suatu kawasan pemukiman menjadi Kawasan Bebas Sampah, diharapkan masyarakat dapat bertanggung jawab menyelesaikan permasalahan sampah di masing-masing wilayahnya. 
Upaya pemerintah lainnya dalam mengurangi sampah dan meningkatkan partisipasi masyarakat adalah program Bank Sampah. Bank Sampah telah berhasil mendorong keterlibatan masyarakat dalam menjaga kebersihan lingkungan melalui kegiatan pemilahan sampah yang akan dibuang. Upaya ini telah mendorong semakin banyak wilayah yang melaksanakan kegiatan bank sampah. Namun, semakin banyaknya wilayah yang menerapkan bank sampah, belum diikuti dengan partisipasi masyarakatnya. Masyarakat yang terlibat di bank sampah jumlahnya masih sangat kecil jika dibandingkan dengan jumlah penduduk kota. Oleh karena itu, bank sampah dinilai efektif dalam mengatasi masalah sampah, namun masih rendahnya partisipasi masyarakat menjadikan program ini belum memperlihatkan hasil yang maksimal.

Berkembangnya kegiatan pengelolaan sampah melalui bank sampah terbukti mampu mengurangi buangan sampah plastik, namun tidak halnya dengan sampah organik. Oleh karena itu, perlu dikembangkan strategi untuk mendorong pengelolaan sampah semakin baik lagi di lingkungan masyarakat Kota Bandung. Salah satu program untuk meningkatkan partisipasi masyarakat dalam pengelolaan sampah yaitu program Kangpisman (Kurangi, Pisahkan dan Manfaatkan Sampah). Kangpisman adalah salah satu inovasi Kota Bandung dalam mengatasi permasalahan sampah dari sumbernya, yaitu rumah tangga. Diharapkan melalui gerakan Kangpisman, sampah di tingkat rumah tangga dipilah dan diolah di lingkungan tersebut, sehingga sampah yang terbuang ke tempat pembuangan akhir akan semakin berkurang.

Program Kangpisman telah dilaksanakan di beberapa wilayah di Kota Bandung, namun belum semua rumah tangga melakukan gerakan Kangpisman. Oleh karena itu, kegiatan sosialisasi dan edukasi gerakan Kangpisman dilakukan untuk meluaskan gerakan Kangpisman ke seluruh wilayah khususnya di Kecamatan Cinambo, sehingga dapat merubah perilaku dan mindset masyarakat untuk peduli terhadap kebersihan lingkungan.

\section{TINJAUAN KONSEPTUAL}

Sosialisasi adalah proses mempelajari norma, nilai, peran dan semua persyaratan lainnya yang diperlukan untuk memungkinkan partisipasi yang efektif dalam kehidupan sosial (Robert Lawang, dalam Universitas Pendidikan Indonesia). Sosialisasi diartikan sebagai suatu proses belajar berinteraksi dengan orang lain tentang cara bertindak, berpikir dan merasakan, dan hal itu penting untuk menghasilkan partisipasi sosial yang efektif. Terkait dengan sosialisasi tentang pengelolaan sampah, yaitu proses belajar tentang cara mengelola sampah 
melalui pendekatan 3R dan berbasiskan masyarakat. 3R adalah kegiatan mengurangi (reduce), menggunakan kembali (reuse) dan mendaur ulang sampah (recycle). Hal ini sesuai dengan yang diamanatkan dalam UU No 18 tahun 2008 tentang Pengelolaan Sampah bahwa pengelolaan sampah merupakan kegiatan sistematis, berkelanjutan yang terdiri dari kegiatan pengurangan dan penanganan. Melalui sosialisasi pengelolaan sampah, maka diharapkan dapat masyarakat mempelajari cara mengelola sampah dengan pendekatan 3R atau Kangpisman (Kurangi, Pisahkan dan Manfaatkan Sampah), sehingga masyarakat dapat berpartisipasi dalam pengelolaan sampah dengan melaksanakan pengelolaan sejak dari sumbernya.

Edukasi adalah segala upaya yang direncanakan untuk mempengaruhi orang lain baik individu, kelompok maupun masyarakat sehingga mereka melakukan apa yang diharapkan oleh pelaku pendidikan (Notoatmojo, 2003). Edukasi merupakan proses belajar dari tidak tahu menjadi tahu. Dalam kaitannya dengan edukasi pengelolaan sampah bagi masyarakat, maka diharapkan masyarakat mengetahui tentang pengelolaan sampah dengan pendekatan 3R, sehingga pengetahuannya dapat mempengaruhi individu, kelompok atau masyarakat di lingkungannya. Kegiatan R ke-1 (reduce) adalah upaya untuk mengurangi timbulan sampah di lingkungan sumber dan dapat dilakukan sejak sebelum sampah dihasilkan dengan cara merubah pola hidup konsumtif, yaitu merubah kebiasaan boros dan menghasilkan banyak sampah menjadi hemat dan sedikit sampah. R ke-2 (reuse) yaitu upaya untuk memakai kembali bahan atau material agar tidak menjadi sampah secara langsung tanpa mengolahnya terlebih dahulu. R ke-3 (recycle) yaitu upaya memanfaatkan kembali sampah melalui daur ulang setelah melalui proses pengolahan tertentu.

\section{DESAIN PENELITIAN}

Kegiatan sosialisasi dan edukasi Kangpisman dilaksanakan di Kecamatan Cinambo Kota Bandung selama 2 bulan, dengan sasaran kegiatan adalah Lurah beserta jajarannya; ketua RW se kelurahan, kader PKK di tingkat kelurahan dan masyarakat aktif dari seluruh RW yang ada di lingkungan kelurahan. Kegiatan dilaksanakan melalui tiga tahapan utama yaitu sosialisasi, edukasi dan evaluasi.

Sosialisasi dilaksanakan dengan tujuan untuk mempelajari cara mengelola sampah dengan pendekatan 3R atau Kangpisman. Kegiatan sosialisasi dilaksanakan melalui metode penyuluhan khususnya materi tentang permasalahan sampah di Kota Bandung; solusi penanganan sampah di wilayah; pelaksanaan program Kangpisman di wilayah; alur 
pengolahan sampah organik dan anorganik; pembagian kerja dalam pengolahan sampah organik dan anorganik; jadwal kerja dalam pengolahan sampah; pihak yang terlibat dalam pengolahan sampah; dan manfaat yang diperoleh dari pengolahan sampah.

Edukasi dilakukan agar masyarakat mengetahui tentang pengelolaan sampah dengan pendekatan 3R atau Kangpisman. Kegiatan edukasi dilaksanakan dengan metoda praktek dengan tujuan peserta dapat memiliki keterampilan. Adapun praktek yang diberikan dalam pengelolaan sampah meliputi praktek pemilahan sampah anorganik dan anorganik; praktek pembuatan MOL; praktek urban farming; praktek pembuatan kerajinan dari daur ulang sampah; praktek door to door education; dan praktek door to door collection.

Evaluasi program dilakukan dengan tujuan untuk mengetahui sampai sejauhmana rencana telah diterapkan dan komponen apa yang perlu diperbaiki. Langkah evaluasi program dilaksanakan dengan memantau pengurangan volume sampah; memantau tingkat perilaku masyarakat dalam memilah sampah; memantau keberlanjutan pengolahan sampah menjadi produk-produk inovatif dan bermanfaat di masyarakat.

\section{HASIL KEGIATAN}

\section{Program Kangpisman}

Kangpisman (Kurangi, Pisahkan, Manfaatkan Sampah) merupakan gerakan pemerintah Kota Bandung dalam melakukan pengolahan sampah yang difokuskan pada penanganan sampah pada sumbernya yaitu rumah tangga. Program ini merupakan program kolaborasi antara pemerintah, warga, swasta dan lainnya dalam membangun peradaban baru pengelolaan sampah melalui upaya mengurangi, memisahkan, dan memanfaatkan sampah. Gerakan ini juga menjadi wujud keseriusan pemerintah Kota Bandung dalam upaya mendorong Kota Bandung semakin bersih dan terbebas dari sampah.

Program Kangpisman didorong menjadi gerakan gaya hidup, karena tanpa adanya pembiasaan kesadaran akan sulit untuk tumbuh. Dengan menjadi gaya hidup, maka diharapkan kesadaran itu menjadi suatu kebiasaan masyarakat khususnya pada masyarakat yang tinggal di kota Bandung. Gerakan Kangpisman telah diimplementasikan ke berbagai pihak hingga ke seluruh RT dan RW di Kota Bandung.

Terkait dengan gerakan Kangpisman, Pemerintah Kota Bandung telah mengeluarkan Peraturan Daerah (Perda) No. 17 Tahun 2012 tentang Pengurangan Penggunaan Kantong Plastik. Langkah yang harus dilakukan dengan program Kangpisman yaitu: Kang (kurangi), yaitu kurangi penggunaan semua yang terbuat dari bahan plastik dan bahan lainnya yang sulit 
diurai oleh alam, seperti kantong plastik, botol/gelas air mineral dan lain-lain. Upaya yang dilakukan yaitu mengganti kantong plastik dengan kantong jinjing yang terbuat dari kain kanvas yg dapat dipakai berulang-ulang. Gunakan juga sedotan dari bambu, atau kaca yang ramah lingkungan. Biasakan membawa kotak makan, tempat minum, sendok dan garpu sendiri. Pis (pisahkan), yaitu pisahkan sampah organik dengan anorganik. Man (manfaatkan), yaitu mengelola sampah organik dan anorganik, sehingga dapat didaur ulang.

Munculnya inisiatif pemerintah Kota Bandung melalui gerakan Kangpisman, menunjukkan keseriusan pemerintah dalam mengatasi sampah dengan membangun infrastuktur dan sistem pengelolaannya. Namun, pengelolaan sampah tidak hanya menjadi urusan pemerintah saja, stakeholder dan masyarakat perlu membantu pemerintah agar gerakan Kangpisman dapat berjalan dengan lancar.

\section{Sosialisasi dan Edukasi Kangpisman}

Kegiatan sosialisasi dan edukasi gerakan Kangpisman dilaksanakan di empat kelurahan dengan pelaksana kegiatan yaitu kader PKK, yang menjadi motor penggerak dari pengolahan sampah yang ada di wilayah. Sosialisasi tentang gerakan Kangpisman disampaikan dengan metode penyuluhan yang meliputi materi tentang permasalahan sampah di Kota Bandung; solusi penanganan sampah, pelaksanaan program Kangpisman, alur pengolahan sampah organik dan anorganik, pembagian kerja dalam pengelolaan sampah, jadwal kerja dalam pengelolaan sampah, pihak yang terlibat dalam pengelolaan sampah, manfaat yang diperoleh dari pengelolaan sampah. Selanjutnya kegiatan edukasi dilakukan dalam bentuk praktik yang meliputi praktik tentang pemilahan sampah anorganik, pembuatan MOL (Mikro Organisme Lokal), pengolahan sampah organik, praktek urban farming, pembuatan kerajinan dari daur ulang sampah, door to door education, door to door collection.

Pada kegiatan sosialisasi, umumnya kader PKK sudah memiliki pengetahuan yang baik tentang Program Kangpisman mulai dari pelaksanaan program di tingkat kota sampai pada tahap pelaksanaan di wilayah. Namun, pemahaman tersebut tidak merata untuk semua wilayah. Salah satu faktor yang menjadikan kurangnya pengetahuan tentang Program Kangpisman adalah masih kurangnya keterlibatan kader PKK dalam meluaskan gerakan Kangpisman di masyarakat, baik melalui pertemuan secara formal maupun informal.

Tabel 1. Hasil Evaluasi kegiatan Sosialisasi Gerakan Kangpisman

\begin{tabular}{|c|l|l|l|l|}
\hline Materi Kegiatan & $\begin{array}{c}\text { Kelurahan } \\
\text { Pakemitan }\end{array}$ & $\begin{array}{c}\text { Kelurahan } \\
\text { Sukamulya }\end{array}$ & $\begin{array}{c}\text { Kelurahan } \\
\text { Cisaranten } \\
\text { Wetan }\end{array}$ & $\begin{array}{c}\text { Kelurahan } \\
\text { Babakan } \\
\text { Penghulu }\end{array}$ \\
\hline Permasasalahan sampah & Dijelaskan & Dijelaskan & Kurang & Dijelaskan \\
\hline
\end{tabular}




\begin{tabular}{|l|l|l|l|l|}
\hline di Kota Bandung & dengan baik & dengan baik & dijelaskan & dengan baik \\
\hline $\begin{array}{l}\text { Solusi penanganan } \\
\text { sampah }\end{array}$ & $\begin{array}{l}\text { Dijelaskan } \\
\text { dengan baik }\end{array}$ & $\begin{array}{l}\text { Dijelaskan } \\
\text { dengan baik }\end{array}$ & $\begin{array}{l}\text { Dijelaskan } \\
\text { cukup baik }\end{array}$ & $\begin{array}{l}\text { Dijelaskan } \\
\text { dengan sangat } \\
\text { baik }\end{array}$ \\
\hline $\begin{array}{l}\text { Alur pengelolaan } \\
\text { sampah }\end{array}$ & $\begin{array}{l}\text { Dijelaskan } \\
\text { dengan baik }\end{array}$ & $\begin{array}{l}\text { Dijelaskan } \\
\text { dengan baik }\end{array}$ & $\begin{array}{l}\text { Dijelaskan } \\
\text { cukup baik }\end{array}$ & $\begin{array}{l}\text { Dijelaskan } \\
\text { dengan sangat } \\
\text { baik }\end{array}$ \\
\hline
\end{tabular}

\begin{tabular}{|l|l|l|l|l|}
\hline \multicolumn{1}{|c|}{ Materi Kegiatan } & \multicolumn{1}{|c|}{$\begin{array}{l}\text { Kelurahan } \\
\text { Pakemitan }\end{array}$} & $\begin{array}{l}\text { Kelurahan } \\
\text { Sukamulya }\end{array}$ & $\begin{array}{l}\text { Kelurahan } \\
\text { Cisaranten } \\
\text { Wetan }\end{array}$ & $\begin{array}{l}\text { Kelurahan } \\
\text { Babakan } \\
\text { Penghulu }\end{array}$ \\
\hline $\begin{array}{l}\text { Pembagian kerja dalam } \\
\text { pengelolaan sampah }\end{array}$ & $\begin{array}{l}\text { Dijelaskan } \\
\text { dengan baik }\end{array}$ & $\begin{array}{l}\text { Dijelaskan } \\
\text { dengan baik }\end{array}$ & $\begin{array}{l}\text { Dijelaskan } \\
\text { cukup baik }\end{array}$ & $\begin{array}{l}\text { Dijelaskan } \\
\text { dengan cukup } \\
\text { baik }\end{array}$ \\
\hline $\begin{array}{l}\text { Jadwal kerja dalam } \\
\text { pengelolaan sampah }\end{array}$ & $\begin{array}{l}\text { Dijelaskan } \\
\text { dengan baik }\end{array}$ & $\begin{array}{l}\text { Dijelaskan } \\
\text { dengan baik }\end{array}$ & $\begin{array}{l}\text { Dijelaskan } \\
\text { cukup baik }\end{array}$ & $\begin{array}{l}\text { Dijelaskan } \\
\text { dengan sangat } \\
\text { baik }\end{array}$ \\
\hline $\begin{array}{l}\text { Pihak-pihak yang } \\
\text { terlibat }\end{array}$ & $\begin{array}{l}\text { Dijelaskan } \\
\text { dengan baik }\end{array}$ & $\begin{array}{l}\text { Dijelaskan } \\
\text { dengan baik }\end{array}$ & $\begin{array}{l}\text { Dijelaskan } \\
\text { cukup baik }\end{array}$ & $\begin{array}{l}\text { Dijelaskan } \\
\text { cukup baik }\end{array}$ \\
\hline Manfaat yang diperoleh & $\begin{array}{l}\text { Dijelaskan } \\
\text { dengan baik }\end{array}$ & $\begin{array}{l}\text { Dijelaskan } \\
\text { dengan baik }\end{array}$ & $\begin{array}{l}\text { Dijelaskan } \\
\text { cukup baik }\end{array}$ & $\begin{array}{l}\text { Dijelaskan } \\
\text { dengan sangat } \\
\text { baik }\end{array}$ \\
\hline
\end{tabular}

(Sumber: Hasil Pengolahan data, 2019)

Berdasarkan hasil evaluasi terhadap kegiatan sosialisasi di empat wilayah, dua wilayah (Kelurahan Pakemitan dan Sukamulya) menunjukkan hasil evaluasi yang baik. Hal ini ditunjukkan oleh pengetahuan yang baik dari kader PKK dalam menyampaikan cara mengelola sampah dengan pendekatan 3R atau Kangpisman yang dijelaskan dengan rinci dan lengkap. Sementara itu, dua wilayah lainnya (Kelurahan Cisaranten Wetan dan Kelurahan Babakan Penghulu) menunjukkan evaluasi kegiatan dengan “cukup baik”, karena materi yang disampaikan kurang rinci dan lengkap.

Terdapat beberapa faktor yang mempengaruhi jalannya kegiatan sosialisasi dan edukasi gerakan Kangpisman. Faktor pendukung kegiatan diantaranya besarnya dukungan dari pemerintah kecamatan dan kelurahan dalam melaksanakan gerakan Kangpisman di wilayah. Dukungan yang diberikan berupa dukungan administrasi, peralatan kegiatan penyuluhan dan pendampingan kepada wilayah-wilayah yang mengembangkan kawasannya menjadi Kawasan Bebas Sampah. Pendukung lainnya adalah adanya pendampingan dan fasilitasi alat-alat pengolahan sampah dari Dinas Lingkungan Hidup dan Kebersihan Kota Bandung seperti peralatan komposter, bata terawang, kontainer dan leaflet. Selanjutnya adalah semangat yang tinggi dari para kader PKK, dan antusias dari masyarakat untuk mengikuti kegiatan sosialisasi dan edukasi gerakan Kangpisman. 
Adapun beberapa faktor yang menghambat kegiatan sosialisasi dan edukasi gerakan Kangpisman diantaranya adalah terbatasnya tingkat pendidikan kader PKK, sehingga pengetahuan yang disampaikan tentang cara mengelola sampah dengan pendekatan 3R atau Kangpisman kurang rinci dan lengkap. Faktor lainnya adalah terbatasnya media dan alat peraga yang dapat digunakan untuk melakukan sosialisasi, sehingga informasi yang disampaikan kepada masyarakat menjadi kurang jelas.

Pada kegiatan edukasi gerakan Kangpisman, dilaksanakan dalam bentuk praktek yang meliputi praktik tentang pemilahan sampah anorganik, pembuatan MOL (Mikro Organisme Lokal), pengolahan sampah organik, praktek urban farming, pembuatan kerajinan dari daur ulang sampah, door to door education, door to door collection.

Pada pelaksanaan kegiatan pengelolaan sampah khususnya sampah anorganik, kader PKK mempraktekkan tentang cara memilah sampah, khususnya sampah rumah tangga. Hal ini dilakukan agar masyarakat sekitar yang ada di lingkungannya dapat mengikuti gerakan yang dilakukan oleh kader PKK. Hasil dari pemilahan sampah dikumpulkan untuk selanjutnya ditimbang dan dijual. Kegiatan ini dapat mendorong masyarakat sekitar untuk mengikutinya karena bernilai ekonomi. Beberapa sampah yang memiliki manfaat, selanjutnya dilakukan daur ulang menjadi kerajinan, sehingga dapat menciptakan peluang bagi pemberdayaan para kader dan masyarakatnya.

Pada pengolahan sampah organik, kader PKK mengarahkan masyarakat sekitar untuk mengolah sampah organik melalui bata terawang atau komposter, sehingga terjadi proses pengomposan. Hasil pengomposan akan dimanfaatkan untuk urban farming yang ada di wilayahnya.

Pada praktek pembuatan cairan MOL (Mikro Organisme Lokal), kader PKK mempraktekkannya secara langsung dengan cara menyatukan semua bahan yang terdiri dari air cucian beras, air kelapa, gula merah/mengkudu, dan sisa buah-buahan. Bahan tersebut diaduk, kemudian cairan tersebut ditutup rapat dan didiamkan selama 2 minggu. Pembuatan ciran MOL menjadi praktek yang menarik bagi semua kader bahkan warga masyarakat, karena cairan MOL memberikan manfaat yang sangat menguntungkan bagi urban farming, bahkan dapat digunakan untuk kebun PKK yang ada di semua wilayah.

Pada praktek door to door education, dilakukan edukasi tentang gerakan Kangpisman ke setiap rumah tangga. Pada kegiatan ini, kader PKK tidak hanya mengedukasi tentang gerakan Kangpisman, tetapi juga membuat kesepakatan dengan warganya untuk melakukan pemilahan sampah dengan menyepakati surat pernyataan bahwa rumah tersebut akan memilah 
sampah. Bagi rumah yang sudah diedukasi oleh kader PKK, maka ditandai dengan sebuah stiker yang berisi pernyataan: “Rumah Ini Sudah Memilah Sampah”.

Pada praktek door to door collection, kegiatan ini dilakukan dengan cara mengumpulkan sampah anorganik dari setiap rumah tangga yang sudah memilah sampah. Sampah anorganik tersebut dikumpulkan dalam sebuah gerobak untuk selanjutnya ditimbang dan dijual. Hasil penjualan dari sampah anorganik menjadi nilai tambah bagi para kader yang telah mengelola sampah di wilayahnya. Keuntungan ini tentunya akan memberikan nilai ekonomi apabila haisl penjualan tersebut dapat diorganisir melalui Bank Sampah.

Hasil evaluasi terhadap kegiatan edukasi Kangpisman menunjukkan bahwa hampir semua kader di semua wilayah telah melakukan edukasi dengan baik bahkan telah menguasainya sebagai praktik yang dilakukan sehari-hari.

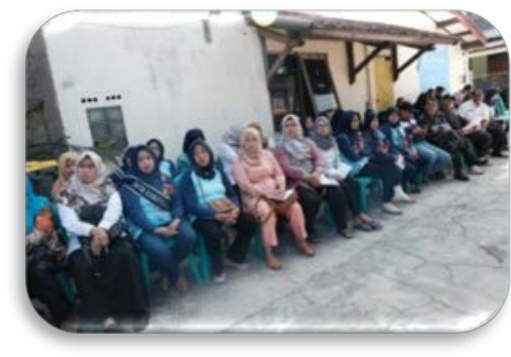

Gambar 1. Sosialisasi dan Edukasi Kangpisman di Kelurahan Pakemitan

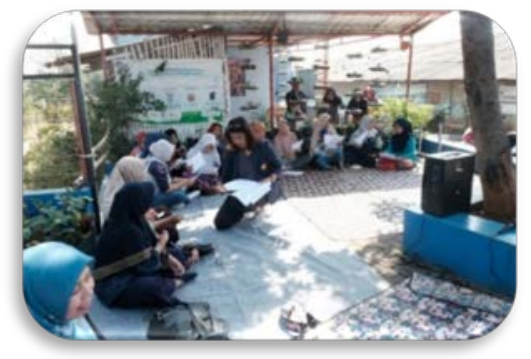

Gambar 3. Sosialisasi dan Edukasi Kangpisman Kelurahan Cisaranten Wetan

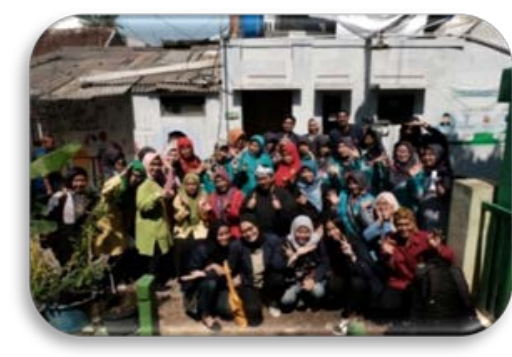

Gambar 2. Sosialisasi dan Edukasi Kangpisman Kelurahan Sukamulya

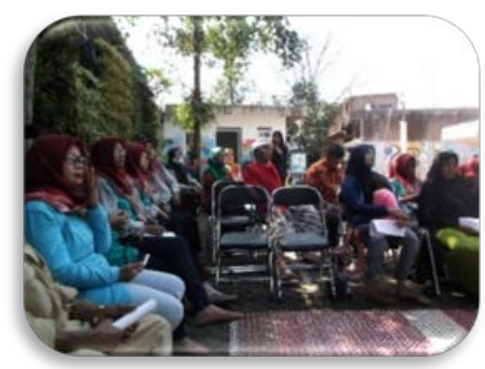

Gambar 4. Sosialisasi dan Edukasi Kangpisman Kelurahan Babakan Penghulu

\section{DISKUSI}

Kegiatan sosialisasi tentang gerakan Kangpisman merupakan proses belajar tentang cara pengelolaan sampah dengan pendekatan 3R atau dikenal dengan Kangpisman (Kurangi, Pisahkan dan Manfaatkan Sampah) yang bertujuan untuk menghasilkan partisipasi yang 
efektif dalam pengelolaan sampah. Hasil kegiatan Pengabdian kepada Masyarakat tentang sosialisasi dan edukasi Kangpisman menunjukkan bahwa kegiatan sosialisasi yang dilakukan oleh kader PKK telah mampu menggerakkan partisipasi masyarakat dalam proses pengelolaan sampah. Hal ini terbukti dari pengetahuan dan pemahaman kader PKK terhadap permasalahan sampah dan pengelolaannya cukup baik disampaikan kepada seluruh warga yang ada di wilayahnya. Begitupun dengan kegiatan edukasi tentang pengelolaan sampah, para kader PKK mampu mempengaruhi warganya untuk melakukan pengelolaan sampah.

Beberapa kajian terdahulu tentang kegiatan sosialisasi dan edukasi pengelolaan sampah menunjukkan hasil yang sama, yaitu mampu meningkatkan pengetahuan dan kesadaran masyarakat tentang pengelolaan sampah. Kajian Affandy, Enik Isnaini, Cicik Herlina Yulianti (2015), menunjukkan bahwa kegiatan sosialisasi tentang pengelolaan sampah sangat penting, karena telah membantu keberhasilan program pemilahan sampah di masyarakat. Kajian Latifatul, Afriezal, Auliya, Kholid (2018) menunjukkan bahwa pemberian pelatihan pengelolaan sampah telah menyebabkan terjadinya penurunan volume sampah. Hal tersebut terjadi karena masyarakat mampu mengaplikasikan materi yang telah diberikan tentang pemilahan dan pewadahan sampah. Kajian Yuliani, Rohidin dan Bieng Brata (2012) menunjukkan bahwa faktor yang paling berpengaruh terhadap perilaku masyarakat diantaranya adalah faktor pendidikan. Pendidikan yang rendah akan mengakibatkan kurangnya pengetahuan tentang pengelolaan sampah. Jadi sosialiasasi berperan penting dalam memberikan pengetahuan kepada masyarakat tentang pengolahan sampah. Kondisi sebaliknya dapat terjadi bahwa kurangnya sosialisasi tentang pengelolaan sampah pada masyarakat dapat menyebabkan pengelolaan sampah menjadi kurang maksimal. Hal ini dikaji oleh Widiyanto, Arif Kurniawan, Elviera Gamelia (2018) bahwa pengelolaan sampah domestik di Kabupaten Banyumas belum maksimal, karena kurangnya sosialisasi tentang pengelolaan sampah domestik.

Terkait dengan kegiatan edukasi tentang pengelolaan sampah, beberapa kajian terdahulu juga menunjukkan hasil yang sama. Kajian Sandika, Anak Agung Gde Ekayana, I Gede Putu Eka Suryana (2018), menunjukkan bahwa kegiatan edukasi pengelolaan sampah kepada masyarakar di Desa Pecatu telah meningkatkan kesadaran masyarakat untuk mengelola dan/atau membiayai pengelolaan sampah yang dihasilkan oleh masyarakat/pemilik usaha, walaupun dalam jumlah yang masih terbatas. Kajian Samadikum (2018) tentang pengaruh pendampingan masyarakat dalam pemilahan sampah, hasilnya menunjukkan bahwa kegiatan edukasi, sosialisasi dan simulasi tentang pemilahan sampah telah memberi kesadaran 
pada masyarakat untuk mengelola sampah. Kajian Asteria dan Heru Heruman (2016), menunjukkan bahwa pembentukkan Bank Sampah yang diintegrasikan dengan edukasi tentang prinsip 4R (Reduce, Reuse, Recycle, Replant) menjadi pengetahuan dasar bagi warga untuk mengelola sampah dari sumbernya, sehingga warga mampu memilah sampah organik dan anorganik. Manfaat dari kemampuan warga untuk mengelola sampah dengan prinsip 4R telah memberi manfaat langsung bagi warganya. Selanjutnya Aisa, Sulthon Arif Rakhman, Difa Ashmamillah, Desi Mutiara Fani, Gilang Aji Pradana (2018), menunjukkan bahwa Enviro School merupakan program edukasi tentang pengelolaan dan pemanfataan sampah, telah berhasil meningkatkan pengetahuan dan kesadaran masyarakat tentang pengelolaan dan pemanfaatan sampah.

Atas dasar hasil kegiatan yang telah dilakukan dan didukung oleh kajian-kajian terdahulu, kegiatan sosialisasi tentang pengelolaan sampah akan berhasil meningkatkan partisipasi masyarakat apabila masyarakat telah memiliki pengetahuan dasar tentang cara mengelola sampah dari sumbernya. Selanjutnya kegiatan edukasi tentang pengelolaan sampah lebih diarahkan pada kemampuan untuk mempengaruhi masyarakat, sehingga masyarakat memiliki kesadaran untuk melakukan pengelolaan dan pemanfataatan sampah.

\section{SIMPULAN}

Tim Penggerak PKK sebagai mitra kegiatan telah memiliki pengetahuan dasar dalam melaksanakan kegiatan sosialisasi dan edukasi gerakan Kangpisman kepada seluruh warga yang ada di wilayahnya, sehingga mampu meningkatkan partisipasi masyarakat dalam melakukan pengolahan sampah dari sumbernya. Sementara itu, edukasi tentang gerakan Kangpisman, kader PKK memiliki kemampuan untuk melakukan praktek pengolahan sampah yang mampu mempengaruhi masyarakatnya baik individu, kelompok maupun masyarakat di wilayahnya, sehingga mereka melakukan pengolahan sampah untuk mewujudkan kawasan yang bersih dan bebas dari sampah. Kegiatan sosialisasi dan edukasi gerakan Kangpisman telah memberikan manfaat pada masyarakat. Hal ini terbukti dari hasil evaluasi kegiatan bahwa peserta kegiatan memperoleh pengetahuan dan keterampilan dalam mengolah sampah. Oleh karena itu, kader PKK yang menjadi mitra kegiatan perlu terus ditingkatkan pengetahuan dan keterampilannya, sehingga menjadi potensi bagi pengembangan wisata edukasi Kangpisman.

\section{UCAPAN TERIMA KASIH}


Kegiatan Pengabdian pada Masyarakat ini didanai melalui skema Hibah Internal Universitas Padjadjaran tahun 2019. Kami mengucapkan terima kasih kepada Camat dan para Lurah di lingkungan Kecamatan Cinambo, para kader PKK dan masyarakat serta mahasiswa KKN tahun 2019 yang telah berpartisipasi dan membantu pelaksanaan kegiatan Pengabdian pada Masyarakat. 


\section{REFERENSI}

Affandy, Enik Isnaini, Cicik Herlina Yulianti. (2015). Peran Serta Masyarakat dalam Pengelolaan Sampah Komprehensif Menuju Zero Waste. Seminar Nasional Sains dan Teknologi Terapan III 2015.

Asteria dan Heru Heruman. (2016). Bank Sampah sebagai Alternatif Pengolahan Sampah Berbasis Masyarakat di Tasikmalaya. Jurnal Manusia dan Lingkungan, Volume 23, No 1, Maret 2016.

Aisa, Sulthon Arif Rakhman, Difa Ashmamillah, Desi Mutiara Fani, Gilang Aji Pradana .(2018). “Enviro School” Rumah Edukasi Pemanfaatan Sampah dalam Rangka Mewujudkan Generasi Peduli Lingkungan. Agrokreatif, Jurnal Ilmiah Pengabdian kepada Masyarakat, Vol 1 (1), Mei 2018.

Bagus Fadhilah Apriadi. (2018). Dampak Tingginya Kepadatan Penduduk di Kota Bandung. Diakses dari https://www.kompasiana.com/bagusfadhilahapriadi0897/5cde7b86733c43571320f52 7/dam (Sandika, 2018)pak-tingginya-kepadatan-penduduk-di-kotabandung?page $=$ all.

Cipta Permana. (2018). Produksi Sampah Kota Bandung Capai 1.600 Ton per Hari, 150 Ton $\begin{array}{llll}\text { di } & \text { Antaranya } & \text { Plastik. } & \text { Diakses }\end{array}$ https://jabar.tribunnews.com/2018/12/03/produksi-sampah-kota-bandung-capai1600-ton-per-hari-150-ton-di-antaranya-plastik.

Latifatul, Afriezal, Auliya, Kholid (2018). Pengaruh Sosialisasi Pemilahan Sampah Organik dan Non Organik serta Manajemen Sampah terhadap Penurunan Volume Sampah di Dusun Krajan Desa Kemunisari Lor Kecamatan Panti Kabupaten Jember. The Indonesian Jurnal of Health Science, Edisi Khusus, September 2018.

Lawang, Robert. (2001). Pengantar Sosiologi. Universitas Terbuka.

Notoatmojo, Soekidjo. (2003). Pendidikan dan Perilaku Kesehatan. Rineka Cipta: Jakarta.

Peraturan Daerah No. 17 Tahun 2012 tentang Pengurangan Penggunaan Kantong Plastik

Sandika, Anak Agung Gde Ekayana, I Gede Putu Eka Suryana (2018), Samadikum (2018). Edukasi Pengelolaan Sampah kepada Masyarakat di Desa Pecatu. Jurnal Ilmiah Populer 1 (1), 61-68. 
Samadikum, Budi Prasetyo. (2018). Pengaruh Pendampingan Masyarakat dalam Pemilahan Sampah di Desa Pucung Kecamatan Tirto Kabupaten Pekalongan. Jurnal Presipitasi: Media Komunukasi dan Pengembangan Teknik Lingkungan, Volume 15, No 1 Maret 2015.

Sekarningrum, Bintarsih, Yogi Suprayogi, Desi Yunita. (2018). Kesadaran Sosial Masyarakat dalam Mewujudkan Kawasan Bebas Sampah di Kecamatan Cinambo Kota Bandung. Bandung: Universitas Padjadjaran.

Undang-undang Republik Indonesia No. 18 Tahun 2008 tentang Pengelolaan Sampah.

Widiyanto, Arif Kurniawan, Elviera Gamelia (2018). Peran Serta Masyarakat dalam Pengelolaan Sampah Domestik sebagai Upaya Pencegahan Penyakit Berbasis Lingkungan. Kes Mas, Jurnal Fakultas Kesehatan Masyarakat, Volume 12, Issue 2, September 2018.

Yuliani, Rohidin dan Bieng Brata (2012). Pengelolaan Sampah di Kecamatan Manna Kabupaten Bengkulu Selatan melalui Pendekatan Sosial Kemasyarakatan. Naturalis, Jurnal Penelitian Pengelolaan Sumberdaya Alam dan Lingkungan, Volume 1 nomor 2, September 2012. 